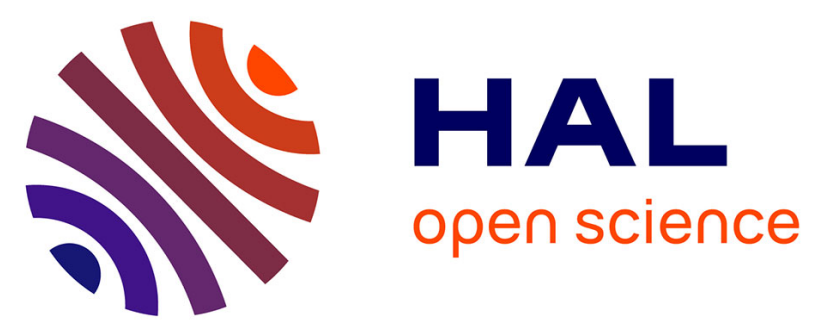

\title{
Reactivity of Functionalized Ynamides with Tetracyanoethylene: Scope, Limitations and Optoelectronic Properties of the Adducts
}

Marie Betou, Raphaël Durand, Antoine Sallustrau, Claire Gousset, Erwann Le Coz, Yann Leroux, Loic Toupet, Elzbieta Trzop, Thierry Roisnel, Yann Trolez

\section{To cite this version:}

Marie Betou, Raphaël Durand, Antoine Sallustrau, Claire Gousset, Erwann Le Coz, et al.. Reactivity of Functionalized Ynamides with Tetracyanoethylene: Scope, Limitations and Optoelectronic Properties of the Adducts. Chemistry - An Asian Journal, 2017, 12 (12), pp.1338-1346. 10.1002/asia.201700353 . hal-01544243

HAL Id: hal-01544243

https://hal-univ-rennes1.archives-ouvertes.fr/hal-01544243

Submitted on 5 Jul 2017

HAL is a multi-disciplinary open access archive for the deposit and dissemination of scientific research documents, whether they are published or not. The documents may come from teaching and research institutions in France or abroad, or from public or private research centers.
L'archive ouverte pluridisciplinaire HAL, est destinée au dépôt et à la diffusion de documents scientifiques de niveau recherche, publiés ou non, émanant des établissements d'enseignement et de recherche français ou étrangers, des laboratoires publics ou privés. 


\title{
Reactivity of functionalized ynamides with tetracyanoethylene: scope, limitations and optoelectronic properties of the adducts
}

Marie Betou, ${ }^{\text {a }}$ Raphaël J. Durand, ${ }^{a}$ Antoine Sallustrau, ${ }^{a}$ Claire Gousset, ${ }^{a}$ Erwann Le Coz, ${ }^{a}$ Yann R. Leroux, ${ }^{a}$ Loïc Toupet, ${ }^{b}$ Elzbieta Trzop, ${ }^{\mathrm{b}}$ Thierry Roisnel, ${ }^{a}$ Yann Trolez ${ }^{*}$

[a] Institut des Sciences Chimiques de Rennes, UMR 6226, CNRS, Ecole Nationale Supérieure de Chimie de Rennes, Université de Rennes 1, 35708 Rennes Cedex (France)

[b] Institut de Physique de Rennes, CNRS, UMR 6251, Université de Rennes 1, 263 avenue du Général Leclerc, 35042 Rennes Cedex (France)

Supporting information for this article is available on the WWW under http://dx.doi.org./xxx
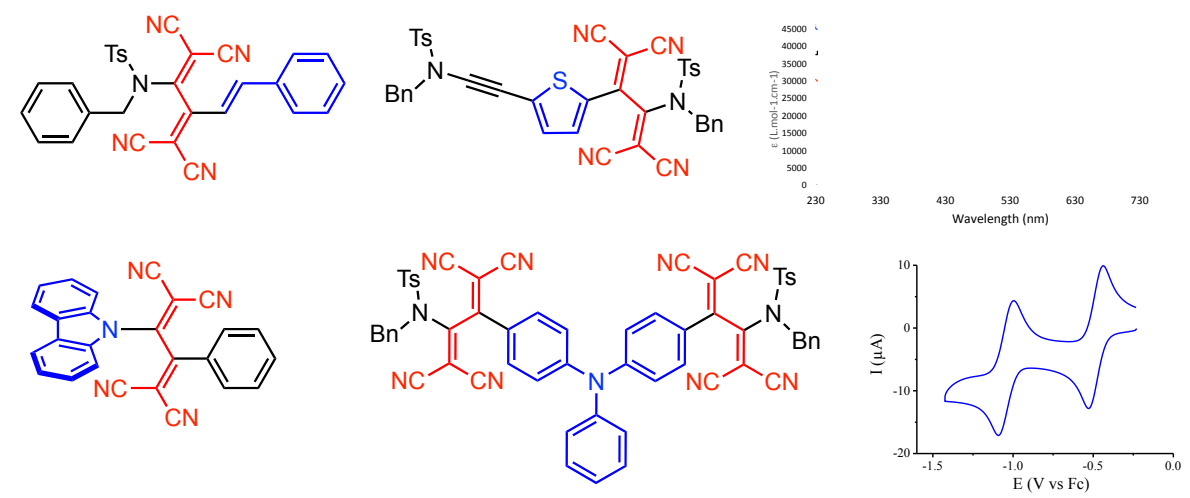

\begin{abstract}
The reactivity of functionalized ynamides and arylynamines with tetracyanoethylene at room temperature has been evaluated. In most cases, the corresponding 1,1,4,4-tetracyanobutadienes (TCBDs) have been obtained in good to excellent yields, following a sequence of [2+2]cycloaddition and [2+2]retroelectrocyclization. The influence of diverse functional groups on the yield of the reaction has been investigated, in particular concerning multiple ynamides. These TCBDs have been characterized by various spectroscopic techniques, electrochemistry and X-Ray diffraction for some of them.
\end{abstract}

\section{Introduction}

The synthesis of 1,1,4,4-tetracyanobutadienes (TCBDs) has met an increasing interest over the last years. ${ }^{[1]}$ Actually, the properties of such molecules could be of particular interest given their exceptional electron-accepting ability and their intense non-linear absorption in some cases. ${ }^{[2]}$ Moreover, their ease of synthesis could also explain their recent rise. Indeed, a certain number of research groups have shown that some organic alkynes activated by an electron-donating group (EDG) could readily react with tetracyanoethylene (TCNE) according to a sequence of [2+2]cycloaddition-retroelectrocyclization (CA-RE) to afford the corresponding TCBDs in variable yields. ${ }^{[3,4]}$ In some examples ( $p$-aniline, azulene, heteroazulene and rich porphyrin substituted alkynes), there is no need for heating the reaction or using an excess of TCNE to reach yields over $90 \% .{ }^{[4]}$ Therefore, this type of 
reaction seems to meet the requirements of the "click" reactions as defined by Sharpless and coworkers in 2001. ${ }^{[5]}$

However, this reaction is very dependent on the nature of the EDG. There is a right balance to find between using an EDG which is rich enough to make the CC triple bond react with TCNE, and an EDG which is too rich and induces an over-reaction of the alkyne with the TCBD itself, producing thus a complex mixture with the formation of multiple oligomers and / or the desired TCBD in bad yield. Following this idea, we recently reported that ynamides ${ }^{[6]}$ could be incorporated in the list of compounds which readily react with TCNE in generally high yields, the nitrogen playing the role of the EDG (scheme 1). ${ }^{[7]}$

We now report on the extension of the scope of the reaction with differently functionalized ynamides, including unsaturated groups that could potentially also react with TCNE or the formed TCBD. ${ }^{[8]}$ Moreover, systems bearing two ynamide functions conjugated to each other were investigated. This study also conducted us to investigate the reactivity of aromatic ynamines.

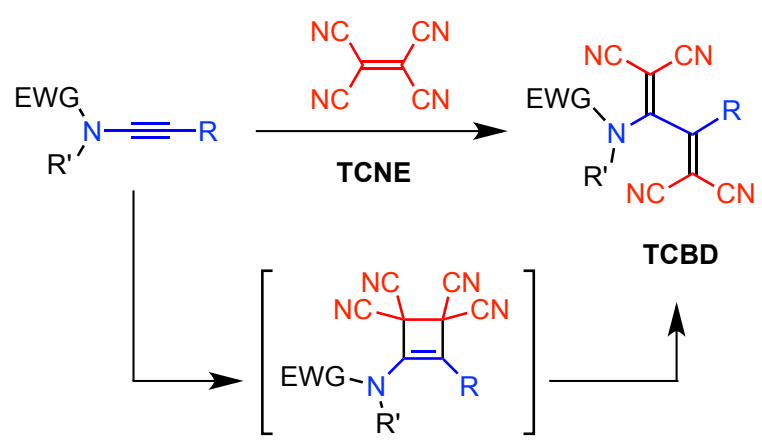

Scheme 1. Reaction between an ynamide and TCNE.

\section{Results and discussion}

We first evaluated the influence of the different three groups of an ynamide (EWG, $R_{1}$ and $R_{2}$ in Table 1). All the experiments used 1 equivalent of TCNE and were carried out in dichloromethane at room temperature during 16 hours (unless otherwise stated).

We started by evaluating the influence of aromatic and heteroaromatic moieties conjugated to the triple bond ( $R_{1}$ in table 1 ). When the phenyl was used, ynamide $1,{ }^{[9]}$ which can be considered in this study as a model compound, allowed for the formation of the corresponding TCBD 2 in 98\% yield (table 1, entry 1 ) as already reported. The phenyl can be substituted by a naphtyl (ynamide $\mathbf{3}$ ) or a p-fluorophenyl group (ynamide 23 ) $^{[10]}$ without any dramatic effect on the yield of the reaction (entries 2 and 12). Heteroaromatic substituents can also be used since furanyl (ynamide 5) and thiophene (ynamide 19) ${ }^{[10]}$ gave the corresponding TCBDs 6 and 20 in 97\% and 87\% yields respectively (entries 3 and 10). Surprisingly, when an anthracenyl substituted in 9-position (ynamide 7) was reacted, no TCBD could be obtained (entry 4). Only the starting material was recovered. No other sidereaction (such as a Diels-Alder cycloaddition) was observed. The rational for such a poor reactivity might come from steric hindrance of protons located in 1 and 8-positions that "protect" the triple bond.

As already observed, the nature of the EWG does not seem to have an influence since replacing the tosyl group by a Boc group (ynamide 21$)^{[11]}$ led to TCBD 22 quantitatively (entry 11). 
We also evaluated the influence of the group linked to the nitrogen $\left(R_{2}\right.$ in table 1$)$. When using a phenyl group (compound 9$)^{[12]}$ instead of benzyl group, the reaction was completely inhibited and the corresponding TCBD 10 was not obtained (entry 5). This observation could be explained by a partial delocalization of the electron doublet of the nitrogen over this phenyl ring, which makes it less available to enrich the CC triple bond. In this case, we thus deduced that the triple bond was not electron-rich enough to react with TCNE. This group could also be replaced by an allyl function (ynamide 11) ${ }^{[10]}$ without any detrimental effect (formation of TCBD 12 in $94 \%$ yield, entry 6). It is noteworthy that there was no further cycloaddition involving the allylic double bond and the TCBD group. One might have anticipated that a Diels-Alder reaction was possible as observed in other similar compounds. ${ }^{[8,13]}$ This system is probably too strained to allow for any further reactions, ${ }^{[14]}$ at least at room temperature. This reaction is also compatible with a propargylic group (ynamide 13) $^{[15]}$ since the corresponding TCBD 14 was obtained in $64 \%$ yield (entry 7 ). Contrary to what was observed with the allylic group, a significant decrease of the yield was observed. Nevertheless, the conversion could be improved to $91 \%$ by stirring the reaction mixture during 58 hours instead of the standard 16 hours. Therefore, a propargylic group does not inhibit the reaction but only slows it down. No further reaction with the terminal triple bond was observed, and as one could have anticipated, the selectivity between the two CC triple bonds present in ynamide $\mathbf{1 3}$ is total.

Then, we tested the influence of a non-aromatic system linked to the triple bond on the $C A-R E$ sequence ( $R_{1}$ in table 1$)$. After observing that a propargylic group could slow down the reaction, we wanted to evaluate the influence of a CC triple bond conjugated to the CC triple bond of an ynamide. Surprisingly, when a phenylacetylene unit was conjugated (ynamide 15), the reaction was completely inhibited and the corresponding TCBD 16 has never been obtained: $95 \%$ of the starting material was recovered after purification (entry 8 ). Heating the reaction mixture did not change the result. A possible reason for this non-reactivity could be that electron density of the CC triple bond linked to the nitrogen might be decreased because of the conjugation with the second triple bond. On the contrary, when a vinyl group was conjugated (ynamide 17), ${ }^{[10]}$ the reaction worked perfectly and gave the expected TCBD 18 in 94\% yield (entry 9). Once again, the presence of the double bond did not induce the formation of by-products or over-reactions. These figures show that the presence of CC double bonds is not detrimental to the formation of TCBDs, contrary to conjugated CC triple bonds. A cyclopropyl group (ynamide 25 ) $^{[16]}$ could also be used to lead to the corresponding TCBD 26 in 86\% yield (entry 13).

Table 1. Influence of the different substituents on the reaction of ynamides with TCNE.

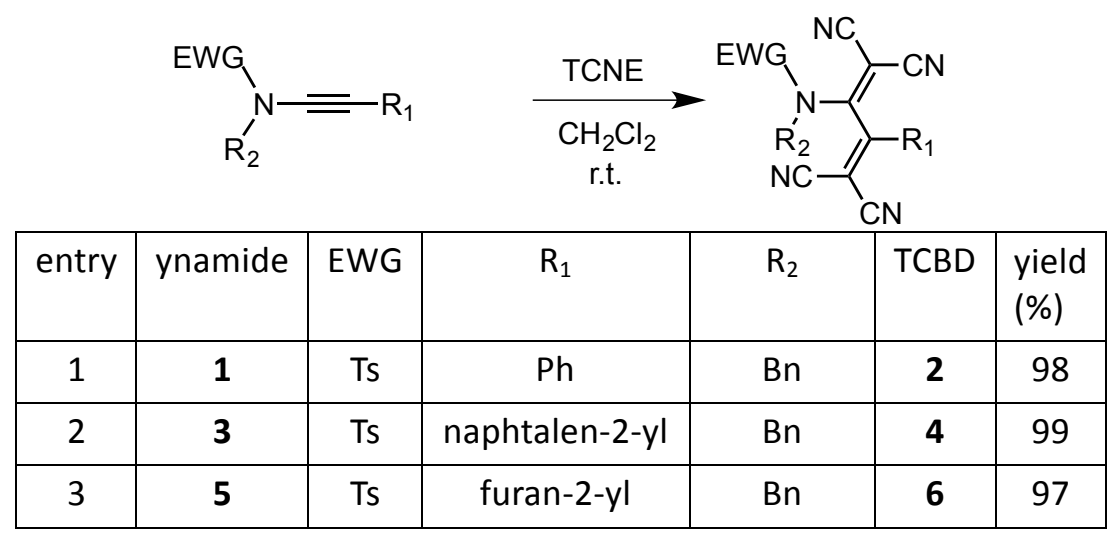




\begin{tabular}{|c|c|c|c|c|c|c|}
\hline $\mathbf{4}$ & $\mathbf{7}$ & Ts & anthracen-9-yl & $\mathrm{Bn}$ & $\mathbf{8}$ & $0^{\text {a }}$ \\
\hline 5 & $\mathbf{9}$ & Ts & Ph & Ph & $\mathbf{1 0}$ & $0^{\text {a }}$ \\
\hline 6 & $\mathbf{1 1}$ & Ts & Ph & allyl & $\mathbf{1 2}$ & 94 \\
\hline 7 & $\mathbf{1 3}$ & Ts & Ph & propargyl & $\mathbf{1 4}$ & $64^{\text {b }}$ \\
\hline $\mathbf{8}$ & $\mathbf{1 5}$ & Ts & - & $\mathrm{Bn}$ & $\mathbf{1 6}$ & $0^{\text {a }}$ \\
\hline 9 & $\mathbf{1 7}$ & Ts & Bn & $\mathbf{1 8}$ & 94 \\
\hline 10 & $\mathbf{1 9}$ & Ts & thiophen-2-yl & $\mathrm{Bn}$ & $\mathbf{2 0}$ & $\mathbf{8 7}$ \\
\hline 11 & $\mathbf{2 1}$ & Boc & Ph & $\mathrm{Bn}$ & $\mathbf{2 2}$ & 99 \\
\hline 12 & $\mathbf{2 3}$ & Ts & p-fluorophenyl & $\mathrm{Bn}$ & $\mathbf{2 4}$ & 99 \\
\hline 13 & $\mathbf{2 5}$ & Ts & cyclopropyl & $\mathrm{Bn}$ & $\mathbf{2 6}$ & 86 \\
\hline
\end{tabular}

${ }^{a}$ No conversion, the starting material was recovered. ${ }^{b}$ When the solution was stirred during $58 \mathrm{~h}$ instead of $16 \mathrm{~h}$, the yield was increased to $91 \%$.

Taking into account that a phenyl group directly linked to the nitrogen of an ynamide completely inhibits the reaction with TCNE, we wondered whether similar compounds without EWG but only aromatic groups could react. For this purpose, three compounds were investigated (Scheme 2). The first one was the acridinone derivative 27. ${ }^{[17]}$ No reaction was observed in this case. The electronic doublet of the nitrogen is probably too delocalized over the aromatic rings rather than the CC triple bond so that it is not reactive enough. The presence of the ketone in addition to aromatic systems conjugated with the nitrogen is probably detrimental to the reaction. This is the reason why another similar compound was tested without this ketone, namely the carbazole ynamine $29 .{ }^{[18]}$ The corresponding TCBD 30 was obtained in a very good yield of $83 \%$. This experiment completes the observation recently made by Kato and collaborators that carbazole is also a good activating group for initiating CA-RE with TCNE. ${ }^{[3 f]}$ Similarly the indole ynamine $31^{[19]}$ was also reacted and provided TCBD 32 in 59\% yield. Concerning the formation of both TCBDs $\mathbf{3 0}$ and 32, no byproducts were isolated. The yield is therefore significantly lower than with ynamides, even though it is important to note that no optimisation of these reactions was attempted. Nevertheless, these last two experiments confirm that arylated ynamines can also provide TCBDs in good yields, ${ }^{[20]}$ contrary to alkylated ynamines that probably over-react with TCNE to lead to a mixture of numerous products in low yields. ${ }^{[7]}$ This observation opens new prospects in the field of optoelectronics for this reaction since compounds $\mathbf{3 0}$ and $\mathbf{3 2}$ both absorb light in the visible range (Figure 2). 

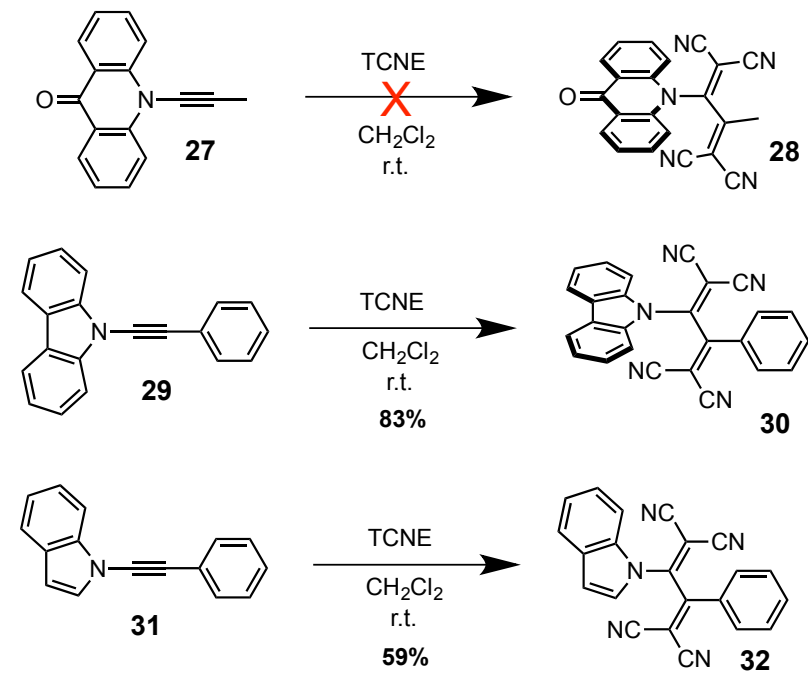

Scheme 2. Evaluation of the reactivity of arylated ynamines.

It is noteworthy to notice that 7,7,8,8-tetracyanoquinodimethane (TCNQ) can also be a good reactant for CA-RE with some activated alkynes, although not as reactive as TCNE. ${ }^{[3 c, 4 d, 21]}$ We tested the reactivity of this compound with some ynamides or ynamines described in this paper, but we never observed the expected reactivity, neither at room temperature nor at higher temperature. The majority of the starting material was recovered. Consequently, we conclude that ynamides are able to react with TCNE but not TCNQ.

TCBDs 4, 6, 14, 18, 20, 24, 26 and $\mathbf{3 0}$ were characterized by X-ray diffraction (Figure 1), additionally to NMR spectroscopy and high-resolution mass spectrometry. As already observed for other TCBDs, the two dicyanovinyls are not in the same plane. The torsion angle measured for the first seven TCBDs is below $90^{\circ}$ (between $60^{\circ}$ and $86^{\circ}$ ) as usually observed for TCBDs whereas for compound 30 it is over $90^{\circ}\left(136^{\circ}\right)$. This is probably due to steric hindrance that precludes the TCBD moiety to stand in s-cis conformation. The orientation of the unsaturated group ( $R_{1}$ in Table 1$)$ linked to the TCBD group differs from one another, depending on their nature. In the case of naphtyl, phenyl fluorophenyl and carbazole groups (compounds $\mathbf{4}, \mathbf{1 4}, \mathbf{2 4}$ and $\mathbf{3 0}$ respectively), the torsion angle between the dicyanovinyl and the aromatic group is comprised between 43 and $63^{\circ}$. In these cases, this observation means that the aromatic groups are fairly conjugated to the TCBD, which can be explained by steric hindrance. On the contrary, in the case of the furanyl, vinyl and thiophenyl groups (compounds 6, 18 and 20), the torsion angle is comprised between $10^{\circ}$ and $20^{\circ}$, meaning that these groups are much more conjugated to the TCBD. This can be explained by their geometrical nature that allows for a less congested conformation. Moreover, an intramolecular $\pi$-stacking is observed between the tosyl group and the aromatic group for naphtyl 4 and for thiophenyl 20. The distance between the tosyl and the aromatic group is 3.4 and $3.5 \AA$ respectively. Intermolecularly, some recurrent interactions can be observed. Numerous $\mathrm{N}-\mathrm{H}$ bond between nitriles and aromatic or benzylic protons are at stake. Tosyl groups also participate to interactions with $\mathrm{O}-\mathrm{H}$ bonds between oxygens of the sulfonamide function and aromatic protons. In only two cases dipole-dipole interactions can be observed between TCBDs in compounds 4 and 20. Intermolecular $\pi$-stacking could not been evidenced, probably because of a too important steric congestion. 


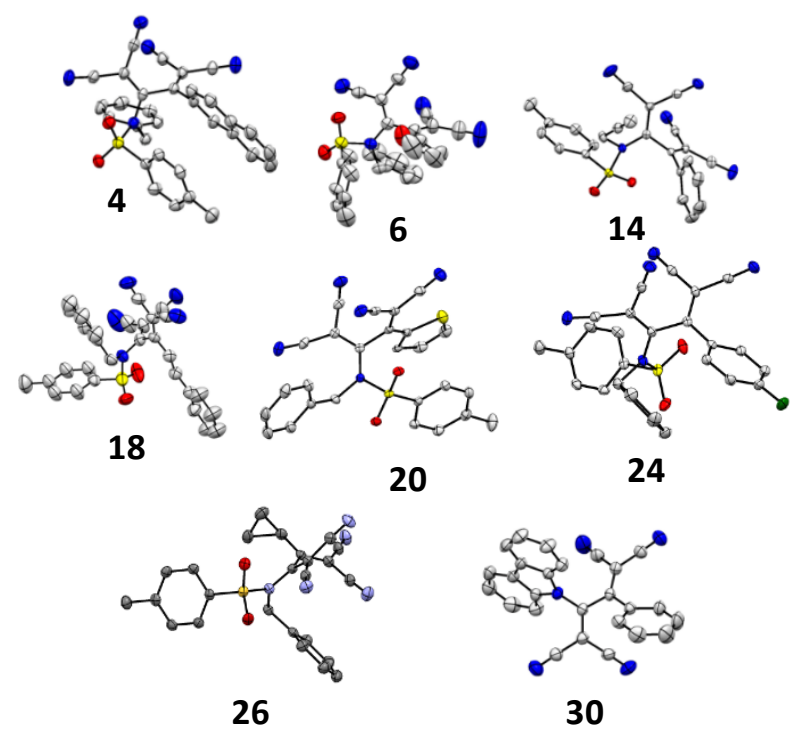

Figure 1. X-ray structure of TCBDs 4, 6, 14, 18, 20, 24, 26 and 30; protons and solvent molecules have been omitted for clarity.

In order to evaluate the possibility to perform multiple TCNE additions on the same molecule, we reacted conjugated bis-ynamides ${ }^{[22]}$ with two equivalents of TCNE in the same conditions as previously described (Scheme 3). We started with mono-phenyl bis-ynamide 33 which was reacted overnight at room temperature with two equivalents of TCNE. The major product obtained was the mono-adduct 34 in 79\% yield. Trace amount of the bisadduct was observed by ${ }^{1} \mathrm{H}$ NMR spectroscopy. The first addition of TCNE probably deactivates the second $\mathrm{CC}$ triple bond because of the strong electron-withdrawing properties of the TCBD moiety. Therefore, the second ynamide function was much less reactive. The same reaction was tested with bis-ynamide $\mathbf{3 5}$ containing a thiophene unit instead of the phenyl group. In that case, the mono-adduct 36 was exclusively formed in $97 \%$ yield, despite the presence of two equivalents of TCNE. The same phenomenon as with bisynamide $\mathbf{3 3}$ is at stake and is even reinforced by the fact that a thiophene is a better conducting unit than a phenyl so that the effect of the presence of one TCBD on the second triple bond is much stronger. This deactivation of the second conjugated triple bond is in major contrast with what has been observed with other good activating groups, ${ }^{[4 b, 4 c, 23]}$ except with porphyrins where such a behavior has also been observed. ${ }^{[4]}$ On the contrary, when using bis-ynamide $\mathbf{3 7}$ containing a triphenylamine spacer, the only isolated product was bis-adduct $\mathbf{3 8}$ (92\% yield). It can be explained by the fact that this unit itself is a strong activating unit ${ }^{[21,24]}$ and that the distance between the two triple bonds (two phenyls and one nitrogen atom) is longer than in the previous cases. The fact that multiple additions of TCNE are possible on the same molecule offers interesting opportunities for the synthesis of larger molecular systems, such as dendrimers ${ }^{[25]}$ or polymers ${ }^{[26]}$ in the future. 

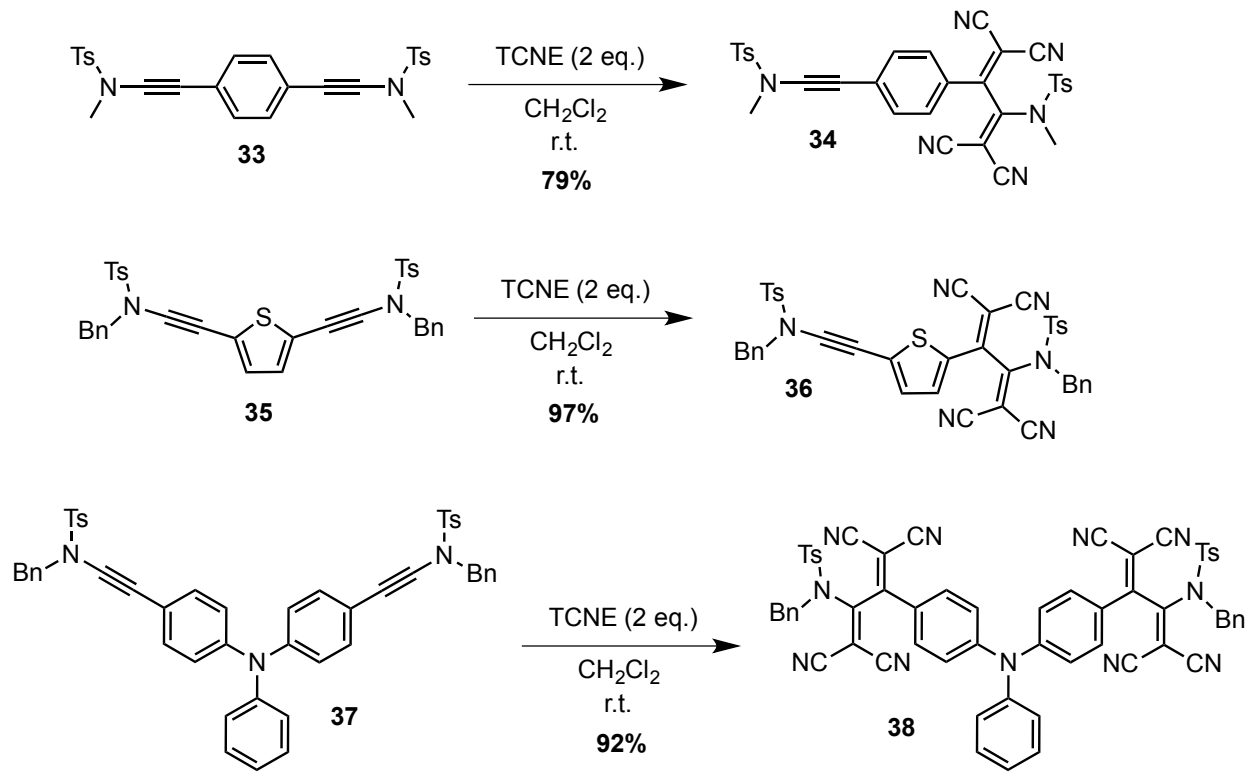

Scheme 3. Evaluation of the reactivity of conjugated bis-ynamides with two equivalents of TCNE.

Most of the new TCBDs were characterized by cyclic voltammetry (figure S1). In general, they exhibit two reversible reduction waves around -0.5 and $-1.0 \mathrm{~V}$ vs ferrocene, which are reminiscent to their electron super-accepting properties (Table 2). Both dicyanovinyl moieties are subsequently reduced with one electron each time. Particularly noteworthy is the case of compound $\mathbf{3 8}$ where two distinct waves were observed around $-0.5 \mathrm{~V}$ vs ferrocene, indicating a significant electronic coupling concerning the first reduction of the two TCBD moieties. The second reduction wave around $-1.0 \mathrm{~V}$ vs ferrocene does not exhibit such a coupling since this reduction appears as one reversible two-electron wave.

Table 2. Reduction potentials of TCBDs 4, 6, 14, 18, 22, 24, 26, 30, 32, 34, 36 and 38. They were measured from cyclic voltammograms presented in figure $\mathrm{S} 3$.

\begin{tabular}{|c|c|c|}
\hline TCBD & $\mathrm{E}_{1 / 2}{ }^{1}(\mathrm{~V}$ vs Fc $)$ & $\mathrm{E}_{1 / 2}{ }^{2}(\mathrm{~V}$ vs Fc $)$ \\
\hline $\mathbf{4}$ & -0.584 & -1.015 \\
\hline $\mathbf{6}$ & -0.611 & -1.028 \\
\hline $\mathbf{1 4}$ & -0.541 & -1.065 \\
\hline $\mathbf{1 8}$ & -0.623 & -0.962 \\
\hline $\mathbf{2 2}$ & -0.611 & -1.172 \\
\hline $\mathbf{2 4}$ & -0.570 & -1.027 \\
\hline $\mathbf{2 6}$ & -0.702 & -1.134 \\
\hline $\mathbf{3 0}$ & -0.483 & -1.044 \\
\hline $\mathbf{3 2}$ & -0.522 & -1.021 \\
\hline $\mathbf{3 4}$ & -0.542 & -1.053 \\
\hline 36 & -0.521 & -0.905 \\
\hline 38 & $-0.520 /-0.630$ & -1.039 \\
\hline
\end{tabular}

The UV-vis absorption properties of these new compounds are very dependent on the nature of the group linked to the TCBD moieties. As indicated in figure 3, compounds 34, 36 and 38 exhibit very different absorption spectra in the visible range, with respective 
absorption maxima at 417, 468 and $604 \mathrm{~nm}$. In particular, compound 38 absorbs in the whole visible range, which allow to envisage different applications in opto-electronic devices. The maximum absorption coefficients of these three species are comprised between $1.2 \mathrm{x}$ $10^{4}$ and $1.8 \times 10^{4} \mathrm{~mol}^{-1}$.L.cm ${ }^{-1}$ in this region.

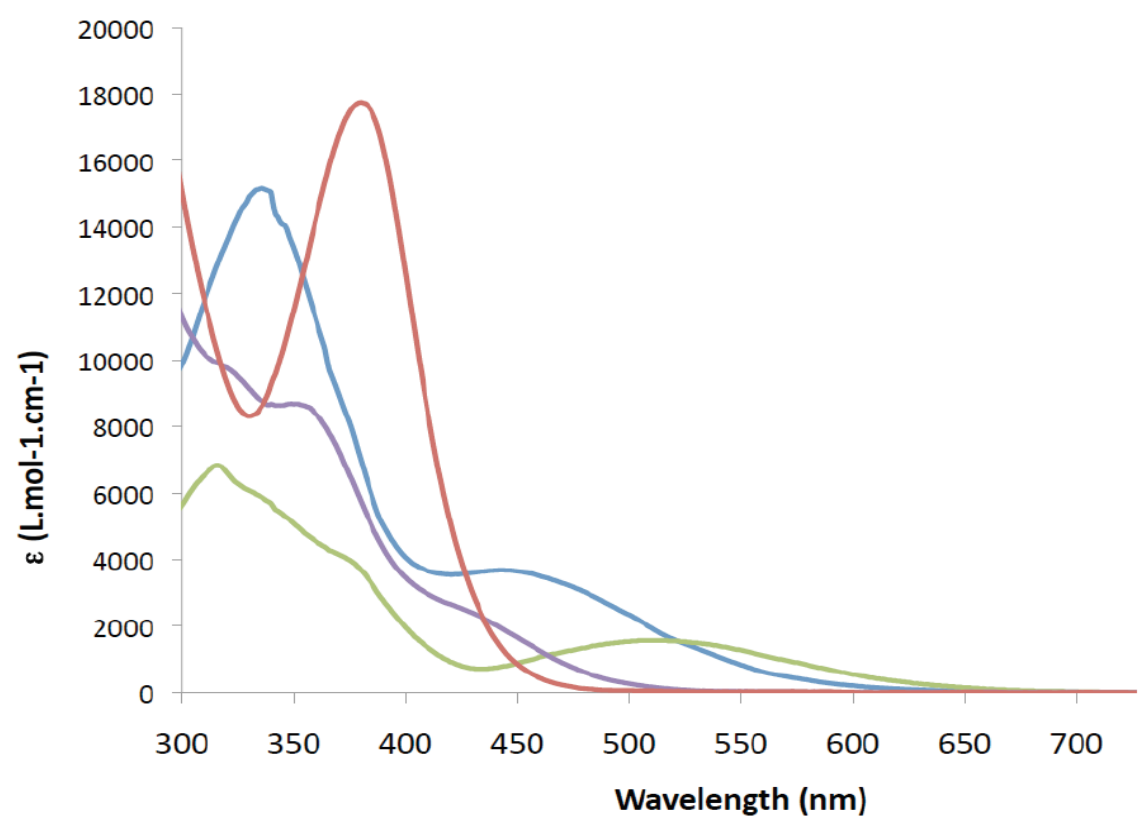

Figure 2. UV-vis spectra of compounds $\mathbf{4}$ (in purple), $\mathbf{6}$ (in red), $\mathbf{3 0}$ (in green) and $\mathbf{3 2}$ (in blue) in dichloromethane.

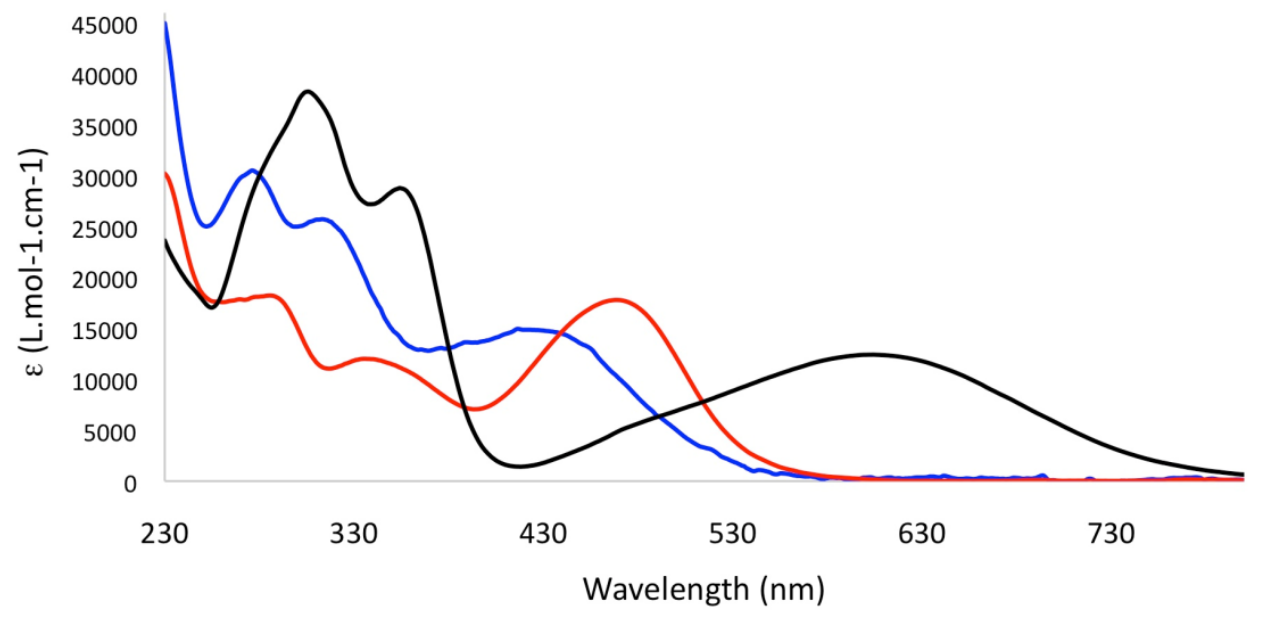

Figure 3. UV-vis spectra of compounds 34 (in blue), 36 (in red) and 38 (in black) in dichloromethane.

To conclude, we have explored the scope and limitations of the reaction between functionalized ynamides or arylynamines and TCNE. In most cases, TCBDs were obtained in good to excellent yields. Only steric hindrance and conjugated triple bonds inhibit the reaction. This study was crucial to evaluate the compatibility of this reactivity with the elaboration of diversely functionalized structures. The possibility to run the reaction several times on the same substrate allows us to potentially build more complex systems for diverse 
applications in different fields such as photovoltaic devices ${ }^{[27]}$ or non-linear absorbers ${ }^{[28]}$ to exploit the exceptional electron-accepting properties of such TCBD moieties.

CCDC 1004149 (4), CCDC 1010768 (6), CCDC 1021633 (14), CCDC 1480922 (18), CCDC 960489 (20), CCDC 1406171 (24), CCDC 1429182 (26) and CCDC 1429183 (30) contain the supplementary crystallographic data for this paper. These data can be obtained free of charge from the Cambridge Crystallographic Data Centre via www.ccdc.cam.ac.uk/data_request/cif.

\section{Experimental Section}

\section{General information}

Reactions were monitored by thin layer chromatography (Merck TLC silica gel $60 \mathrm{~F}_{254}$ on aluminum sheets) and visualized under UV irradiation at $254 \mathrm{~nm}$ or $\mathrm{KMnO}_{4}$ staining solution. Compounds were purified by column chromatography using Geduran ${ }^{\circ}$ silica gel 60 (0.040 $0.063 \mathrm{~nm}$ ). NMR spectra were recorded on Bruker Avance $400 \mathrm{MHz}$ spectrometer. Spectra were recorded in deuterochloroform referenced to residual $\mathrm{CHCl}_{3}\left({ }^{1} \mathrm{H}, 7.26 \mathrm{ppm}\right)$ or $\mathrm{CDCl}_{3}$ $\left({ }^{13} \mathrm{C}, 77.2 \mathrm{ppm}\right)$. Chemical shifts $(\delta)$ are reported in ppm and coupling constants $(J)$ are reported in $\mathrm{Hz}$. The following abbreviations are used to describe multiplicity: s-singlet, $\mathrm{d}$ doublet, t-triplet, dt-doublet of triplet, td-triplet of doublet, tt-triplet of triplet, ddd-doublet of doublet of doublet, ddt-doublet of doublet of triplet and m-multiplet. HRMS experiments were carried out on a Waters Q-Tof 2 (ESI) spectrometer.

\section{Electrochemical experiments}

\section{Electrochemical Setup and Procedure}

All electrochemical measurements were performed with an Autolab PGSTAT 12 (Metrohm) and a conventional three-electrode system, comprising a glassy carbon (GC) electrode as working electrode, a platinum wire as the auxiliary electrode, and SCE electrode (Metrohm) as reference electrode. Ferrocene/ferrocenium redox couple was used as an internal reference and all potential are indicated versus this redox couple for clarity. The GC electrodes were purchased from $\mathrm{CH}$ Instrument, Inc. (Tx, USA) as 2-mm-diameter rods. The electrodes were polished with grit. $4000 \mathrm{SiC}$ paper (Struers) wetted with Milli-Q water. The electrodes were thoroughly rinsed with Milli-Q water and acetone. The electrodes were dried with an argon gas stream, before measurements.

\section{Crystallography}

All measurements were made in the x-scan technique on a CCD Saphire 3 Xcalibur (Oxford Diffraction) or an APEXII Bruker-AXS diffractometer with graphite monochromatized Mo Ka radiation. The structure was solved by direct methods. ${ }^{[29]}$ The non-hydrogen atoms were refined anisotropically by the full-matrix least-square techniques using the program 
SHELX $297 .{ }^{[30]}$ All the hydrogen atoms bonded to $\mathrm{C}$ atoms were located geometrically and treated using a riding model, with $\mathrm{C}-\mathrm{H}=0.95-1.00 \AA$ and $\mathrm{Uiso}(\mathrm{H})=1.2$ or $1.5 \mathrm{Ueq}(\mathrm{C})$.

\section{Synthesis}

\section{Compound 4}

A solution of ynamide 3 (200 mg, $0.486 \mathrm{mmol}$ ) and TCNE $(62.0 \mathrm{mg}, 0.486 \mathrm{mmol})$ in $\mathrm{CH}_{2} \mathrm{Cl}_{2}$ (5 $\mathrm{mL}$ ) was stirred at r.t. for $16 \mathrm{~h}$. The mixture was concentrated under reduced pressure and purified by column chromatography (pentane:EtOAc 8:2) to give TCBD 4 (260 mg, 0.482 mmol, 99\%) as an orange solid. ${ }^{1} \mathrm{H}$ NMR $\left(400 \mathrm{MHz}, \mathrm{CDCl}_{3}\right) \delta 7.92(\mathrm{~d}, J=8.1 \mathrm{~Hz}, 1 \mathrm{H}), 7.87(\mathrm{dt}, J$ $=8.7,2.5 \mathrm{~Hz}, 3 \mathrm{H}), 7.73-7.59(\mathrm{~m}, 3 \mathrm{H}), 7.47(\mathrm{~d}, J=1.8 \mathrm{~Hz}, 1 \mathrm{H}), 7.42(\mathrm{~d}, J=8.3 \mathrm{~Hz}, 2 \mathrm{H}), 7.33-$ $7.25(\mathrm{~m}, 2 \mathrm{H}), 7.09(\mathrm{t}, J=7.8 \mathrm{~Hz}, 2 \mathrm{H}), 6.99(\mathrm{dd}, J=8.2,1.1 \mathrm{~Hz}, 2 \mathrm{H}), 4.74(\mathrm{~s}, 2 \mathrm{H}), 2.49(\mathrm{~s}, 3 \mathrm{H})$. ${ }^{13} \mathrm{C}$ NMR $\left(100 \mathrm{MHz} \mathrm{CDCl}_{3}\right) \delta 166.2,158.7,147.4,135.2,133.3,132.4,131.1,130.9,130.2$, $129.9,129.8,129.6,129.5,129.3,129.2,128.4,128.1,127.6,127.0,124.3,111.7,111.6$, $111.3,111.2,93.7,81.9,52.8,21.9$. HRMS (ESI) calculated for $\mathrm{C}_{32} \mathrm{H}_{21} \mathrm{~N}_{5} \mathrm{NaO}_{2} \mathrm{~S}[\mathrm{M}+\mathrm{Na}]^{+}$ 562.13137, found 562.1315. UV-visible spectroscopy $\left(\mathrm{CH}_{2} \mathrm{Cl}_{2}\right): \lambda_{\max }(\log \varepsilon)=263(4.47), 349$ (3.93) $\mathrm{nm}$. Crystal data: Crystallogenesis: liquid diffusion from a $\mathrm{CH}_{2} \mathrm{Cl}_{2}$ solution into cyclohexane; Formula: $\mathrm{C}_{32} \mathrm{H}_{21} \mathrm{~N}_{5} \mathrm{O}_{2} \mathrm{~S}$, Temperature: $130(2) \mathrm{K}$, Wavelength: $0.71073 \AA$, Crystal system: Monoclinic, space group, $\mathrm{P} 21 / \mathrm{c}$, Unit cell dimensions: $a=13.4821(2) \AA, b=$ 16.6381(3) $\AA, c=13.6268(2) \AA, \alpha=90^{\circ}, \beta=119.292(2)^{\circ}, \gamma=90^{\circ}$, Volume: $2665.88(9) \AA^{3}, Z=4$, Calculated density: $1.344 \mathrm{Mg} / \mathrm{m}^{3}$, Absorption coefficient $0.161 \mathrm{~mm}^{-1}, \mathrm{~F}(000): 1120$, Crystal size: $0.224 \times 0.169 \times 0.109 \mathrm{~mm}^{3}$, Theta range for data collection: 2.99 to $27.00^{\circ}$, Limiting indices: $-17<=\mathrm{h}<=16,-21<=\mathrm{k}<=12,-17<=\mathrm{k}<=17$, Reflections collected / unique: 23487 / 5821 $[R($ int $)=0.0856]$, Completeness to theta $=27.00^{\circ}, 99.9 \%$, Absorption correction: None, Refinement method: Full-matrix least-squares on F2, Data / restraints / parameters: 5821 / 0 / 362, Goodness-of-fit on F2: 1.020, Final R indices [I>2sigma(I)]: R1 $=0.0641$, wR2 $=0.1492$, $R$ indices (all data) $: R 1=0.1092, w R 2=0.1799$, Largest diff. peak and hole $: 0.615$ and -0.460 e. $A^{-3}$.

\section{Compound 6}

A solution of ynamide 5 (200 mg, $0.569 \mathrm{mmol}$ ) and TCNE (72.9 mg, $0.569 \mathrm{mmol}$ ) in $\mathrm{CH}_{2} \mathrm{Cl}_{2}$ $(5.5 \mathrm{~mL})$ was stirred at r.t. for $16 \mathrm{~h}$. The mixture was concentrated under reduced pressure and purified by column chromatography (pentane:EtOAc 7:3) to give TCBD 6 (266 mg, 0.555 mmol, 97\%) as a yellow solid. ${ }^{1}$ H NMR $\left(400 \mathrm{MHz}, \mathrm{CDCl}_{3}\right) \delta 7.93(\mathrm{~d}, J=8.5 \mathrm{~Hz}, 2 \mathrm{H}), 7.66(\mathrm{dd}, J$ $=1.8,0.5 \mathrm{~Hz}, 1 \mathrm{H}), 7.46-7.42(\mathrm{~m}, 3 \mathrm{H}), 7.39(\mathrm{dd}, J=5.0,1.8 \mathrm{~Hz}, 3 \mathrm{H}), 7.27(\mathrm{~d}, J=3.9 \mathrm{~Hz}, 2 \mathrm{H})$, $6.72-6.69(\mathrm{~m}, 1 \mathrm{H}), 4.93(\mathrm{~s}, 2 \mathrm{H}), 2.49(\mathrm{~s}, 3 \mathrm{H}) .{ }^{13} \mathrm{C}$ NMR $\left(100 \mathrm{MHz}, \mathrm{CDCl}_{3}\right) \delta 157.1,150.0$, 148.2 , 147.5, 145.2, 133.2, 132.5, 130.9, 129.6, 129.4, 128.9, 128.8, 123.5, 115.2, 111.9, $111.5,111.5,111.4,83.3,80.5,53.7,21.9$. HRMS (ESI) calculated for $\mathrm{C}_{26} \mathrm{H}_{17} \mathrm{~N}_{5} \mathrm{NaO}_{3} \mathrm{~S}[\mathrm{M}+\mathrm{Na}]^{+}$ 502.09498, found 502.0948. UV-visible spectroscopy $\left(\mathrm{CH}_{2} \mathrm{Cl}_{2}\right): \lambda_{\max }(\log \varepsilon)=281(4.31), 380$ (4.25) $\mathrm{nm}$. Crystal data: Crystallogenesis: liquid diffusion from a $\mathrm{CH}_{2} \mathrm{Cl}_{2}$ solution into cyclohexane; Formula: $\mathrm{C}_{26} \mathrm{H}_{17} \mathrm{~N}_{5} \mathrm{O}_{3} \mathrm{~S}$, Temperature: $250 \mathrm{~K}$, Wavelength: $0.71073 \AA$, Crystal system: Triclinic, space group: P-1, Unit cell dimensions: $a=8.0434(6) \AA, b=9.1866(8) \AA, c=$ 17.657(10) $\AA, \alpha=92.121(7)^{\circ}, \beta=99.213(7)^{\circ}, \gamma=110.069(7)^{\circ}$, Volume: $1203.71(15) \AA^{3}, Z=2$, Calculated density: $1.323 \mathrm{Mg} / \mathrm{m}^{3}$, Absorption coefficient $0.172 \mathrm{~mm}^{-1}, \mathrm{~F}(000)$ : 496 , Crystal size: $0.263 \times 0.131 \times 0.081 \mathrm{~mm}^{3}$, Theta range for data collection: 3.05 to $27.00^{\circ}$, Limiting indices: $-9<=\mathrm{h}<=10,-11<=\mathrm{k}<=11,-22<=\mid<=20$, Reflections collected / unique: $9231 / 5247$ 
$[R$ (int) $=0.0449]$, Completeness to theta $=27.00^{\circ}, 99.8 \%$, Absorption correction: None, Refinement method: Full-matrix least-squares on F2, Data / restraints / parameters: 5247 / 0 / 316, Goodness-of-fit on F2: 1.002, Final R indices [I>2sigma(I)]: R1 $=0.0634$, wR2 $=0.1384$, $R$ indices (all data) $: R 1=0.1216, w R 2=0.1767$, Largest diff. peak and hole $: 0.317$ and -0.238 e. $A^{-3}$.

\section{Compound 12}

A solution of ynamide 11 (105 mg, $0.337 \mathrm{mmol}$ ) and TCNE $(43.3 \mathrm{mg}, 0.337 \mathrm{mmol})$ in $\mathrm{CH}_{2} \mathrm{Cl}_{2}$ $(3.4 \mathrm{~mL}$ ) was stirred at r.t. for $16 \mathrm{~h}$. The mixture was concentrated under reduced pressure and purified by column chromatography (pentane to pentane:EtOAc 8:2) to give TCBD 12 (140 mg, $0.318 \mathrm{mmol}, 94 \%)$ as a yellow solid. ${ }^{1} \mathrm{H}$ NMR $\left(400 \mathrm{MHz}, \mathrm{CDCl}_{3}\right) \delta 7.76(\mathrm{dt}, J=8.8$, $1.6 \mathrm{~Hz}, 2 \mathrm{H}), 7.68(\mathrm{tt}, J=7.2,1.6 \mathrm{~Hz}, 1 \mathrm{H}), 7.58-7.63(\mathrm{~m}, 2 \mathrm{H}), 7.53-7.56(\mathrm{~m}, 2 \mathrm{H}), 7.43(\mathrm{~d}, J=$ $8.0 \mathrm{~Hz}, 2 \mathrm{H}), 5.41-5.45(\mathrm{~m}, 2 \mathrm{H}), 5.30$ (ddt, $J=17.2,9.6,6.4 \mathrm{~Hz}, 1 \mathrm{H}), 4.28(\mathrm{~d}, J=6.4 \mathrm{~Hz}, 2 \mathrm{H})$, $2.49(\mathrm{~s}, 3 \mathrm{H}) .{ }^{13} \mathrm{C}$ NMR $\left(100 \mathrm{MHz}, \mathrm{CDCl}_{3}\right) \delta 166.2,159.4,147.4,133.7,133.0,131.1,130.9$, $129.8,129.4,128.3,128.1,124.4,111.8,111.3,111.2,110.6,93.0,82.7,53.2,21.9$. HRMS (ESI) calculated for $\mathrm{C}_{24} \mathrm{H}_{17} \mathrm{~N}_{5} \mathrm{NaO}_{2} \mathrm{~S}[\mathrm{M}+\mathrm{Na}]^{+}$462.1001, found 462.1006; calculated for $\mathrm{C}_{24} \mathrm{H}_{17} \mathrm{KN}_{5} \mathrm{O}_{2} \mathrm{~S}[\mathrm{M}+\mathrm{K}]^{+}$478.0740, found 478.0766.

\section{Compound 14}

A solution of ynamide 13 ( $82.1 \mathrm{mg}, 0.265 \mathrm{mmol}$ ) and TCNE $\left(33.9 \mathrm{mg}, 0.265 \mathrm{mmol}\right.$ ) in $\mathrm{CH}_{2} \mathrm{Cl}_{2}$ $(8 \mathrm{~mL})$ was stirred overnight at r.t. for $16 \mathrm{~h}$. The mixture was concentrated under reduced pressure and purified by column chromatography (pentane:EtOAc 8:2) to give TCBD 12 (72.2 $\mathrm{mg}, 0.167 \mathrm{mmol}, 64 \%)$ as a beige solid. ${ }^{1} \mathrm{H}$ NMR $\left(400 \mathrm{MHz}, \mathrm{CDCl}_{3}\right) \delta 7.75-7.71(\mathrm{~m}, 2 \mathrm{H}), 7.68$ $-7.64(\mathrm{~m}, 3 \mathrm{H}), 7.60-7.55(\mathrm{~m}, 2 \mathrm{H}), 7.43(\mathrm{~d}, J=8.0 \mathrm{~Hz}, 2 \mathrm{H}), 4.48(\mathrm{~d}, J=2.5 \mathrm{~Hz}, 2 \mathrm{H}), 2.70(\mathrm{t}, J=$ $2.5 \mathrm{~Hz}, 1 \mathrm{H}), 2.48(\mathrm{~s}, 3 \mathrm{H}) .{ }^{13} \mathrm{C}$ NMR $\left(100 \mathrm{MHz}, \mathrm{CDCl}_{3}\right) \delta 165.4,158.2,147.7,133.9,132.3,131.2$, $130.8,129.9,129.7,128.1,111.8,111.6,110.7,110.1,92.2,85.1,79.9,73.7,41.1,21.9$. HRMS (ESI) calculated for $\mathrm{C}_{24} \mathrm{H}_{15} \mathrm{~N}_{5} \mathrm{NaO}_{2} \mathrm{~S}[\mathrm{M}+\mathrm{Na}]^{+} 460.0844$, found 460.0844. Crystal data: Crystallogenesis: liquid diffusion from a $\mathrm{CH}_{2} \mathrm{Cl}_{2}$ solution into cyclohexane; Formula: $\mathrm{C}_{24} \mathrm{H}_{15} \mathrm{~N}_{5} \mathrm{O}_{2} \mathrm{~S}$, Temperature: $140 \mathrm{~K}$, Wavelength: $0.71073 \AA$, Crystal system: monoclinic, space group: P 21/c, Unit cell dimensions: $a=8.6183(2) \AA, b=13.0256(3) \AA, c=20.2405(5) \AA, \alpha=$ $90^{\circ}, \beta=100.456(2)^{\circ}, \gamma=90^{\circ}$, Volume: $2234.44(9) \AA^{3}, Z=4$, Calculated density: $1.300 \mathrm{Mg} / \mathrm{m}^{3}$, Absorption coefficient $0.176 \mathrm{~mm}^{-1}, \mathrm{~F}(000)$ : 904 , Crystal size: $0.218 \times 0.167 \times 0.114 \mathrm{~mm}^{3}$, Theta range for data collection: 3.188 to $26.999^{\circ}$, Limiting indices: $-10<=\mathrm{h}<=11,-16<=\mathrm{k}<=16$, $-25<=\mid<=25$, Reflections collected / unique: $17112 / 4857$ [R(int $)=0.0495$ ], Completeness to theta $=25.242^{\circ}, 99.8 \%$, Absorption correction: None, Refinement method: Full-matrix leastsquares on F2, Data / restraints / parameters: 4857 / 0 / 290, Goodness-of-fit on F2: 0.975, Final $R$ indices [l>2sigma(I)]: R1 $=0.0428, w R 2=0.0920, R$ indices (all data) $: R 1=0.0709$, $W R 2=0.1079$, Largest diff. peak and hole $: 0.251$ and -0.369 e. $A^{-3}$.

\section{Compound 18}

A solution of ynamide 17 ( $88.3 \mathrm{mg}, 0.228 \mathrm{mmol})$ and TCNE $(29.2 \mathrm{mg}, 0.228 \mathrm{mmol})$ in $\mathrm{CH}_{2} \mathrm{Cl}_{2}$ $(2.3 \mathrm{~mL})$ was stirred at r.t. for $16 \mathrm{~h}$. The mixture was concentrated under reduced pressure and purified by column chromatography (pentane to pentane:EtOAC 8:2) to give TCBD 12 (111 mg, $0.215 \mathrm{mmol}, 94 \%)$ as an orange solid. ${ }^{1} \mathrm{H}$ NMR (400 MHz, $\left.\mathrm{CDCl}_{3}\right) \delta 8.02(\mathrm{~d}, J=8.5 \mathrm{~Hz}$, $1 \mathrm{H}), 7.55-7.35(\mathrm{~m}, 11 \mathrm{H}), 7.26-7.21(\mathrm{~m}, 3 \mathrm{H}), 7.04(\mathrm{~d}, J=16.1 \mathrm{~Hz}, 1 \mathrm{H}), 4.88(\mathrm{~s}, 2 \mathrm{H}), 2.48(\mathrm{~s}$, 3H). ${ }^{13} \mathrm{C}$ NMR $\left(100 \mathrm{MHz} \mathrm{CDCl}_{3}\right) \delta 160.4,157.7,148.2,147.7,133.4,132.9,132.8,132.7$, 
130.9, 129.9, 129.7, 129.6, 129.5, 129.1, 128.4, 119.6, 111.6, 111.3, 111.0, 110.9, 88.6, 53.0, 52.9, 21.9. HRMS (ESI) calculated for $\mathrm{C}_{30} \mathrm{H}_{21} \mathrm{~N}_{5} \mathrm{NaO}_{2} \mathrm{~S}[\mathrm{M}+\mathrm{Na}]^{+} 538.1314$, found 538.1321; calculated for $\mathrm{C}_{30} \mathrm{H}_{21} \mathrm{KN}_{5} \mathrm{O}_{2} \mathrm{~S} \quad[\mathrm{M}+\mathrm{K}]^{+}$554.1053, found 554.1054. Crystal data: Crystallogenesis: slow evaporation of a $\mathrm{CH}_{2} \mathrm{Cl}_{2}$ solution; Formula: $\mathrm{C}_{30} \mathrm{H}_{21} \mathrm{~N}_{5} \mathrm{O} \mathrm{O}_{2} \mathrm{~S}$, Temperature: 295 K, Wavelength: $0.71073 \AA$, Crystal system: Monoclinic, space group, P 21/c, Unit cell dimensions: $a=16.6788(6) \AA, b=17.3511(9) \AA, c=9.4234(5) \AA, \alpha=90^{\circ}, \beta=94.829(2)^{\circ}, \gamma=$ 90', Volume: $2717.4(2) \AA^{3}, Z=4$, Calculated density: $1.260 \mathrm{~g} . \mathrm{cm}^{3}$, Absorption coefficient $0.155 \mathrm{~mm}^{-1}, \mathrm{~F}(000): 1072$, Crystal size: $0.340 \times 0.160 \times 0.090 \mathrm{~mm}^{3}$, Theta range for data collection: 3.197 to $27.483^{\circ}$, Limiting indices: $-18 \leq h \leq 21,-13 \leq k \leq 22,-11 \leq 1 \leq 12$, Reflections collected / unique: $18561 / 6197$ [R(int) $=0.0297]$, Completeness to theta $=99.5 \%$, Absorption correction: multi-scan, Refinement method: Full-matrix least-squares on F2, Data / restraints / parameters: 6197 / 0 / 248, Goodness-of-fit: 1.059, Final R indices [I>2sigma(I)]: $\mathrm{R} 1 \mathrm{a}=0.0858, \mathrm{wR} 2 \mathrm{~b}=0.2778, \mathrm{R}$ indices (all data) $: \mathrm{R} 1 \mathrm{a}=0.1445, \mathrm{wR} 2 \mathrm{~b}=0.3319$, Largest diff. peak and hole : 0.626 and -0.501 e. $A^{-3}$.

\section{Compound 20}

The spectroscopic data are similar to those reported in the literature. ${ }^{[7]}$ Crystal data: Crystallogenesis: liquid diffusion from a $\mathrm{CH}_{2} \mathrm{Cl}_{2}$ solution into cyclohexane; Formula: $\mathrm{C}_{26} \mathrm{H}_{17} \mathrm{~N}_{5} \mathrm{O}_{2} \mathrm{~S}_{2}$, Temperature: $100 \mathrm{~K}$, Wavelength: $0.71073 \AA$, Crystal system: Monoclinic, space group, $P$ 21/n, Unit cell dimensions: $a=13.5158$ (3) $\AA, b=10.2890$ (2) $\AA, c=17.4575(3)$ $\AA, \alpha=90^{\circ}, \beta=108.622(2)^{\circ}, \gamma=90^{\circ}$, Volume: $2300.61(8) \AA^{3}, Z=4$, Calculated density: 1.431 g.cm ${ }^{3}$, Absorption coefficient $0.267 \mathrm{~mm}^{-1}, \mathrm{~F}(000): 1024$, Crystal size: $0.268 \times 0.154 \times 0.147$ $\mathrm{mm}$, Theta range for data collection: 3.04 to $26.99^{\circ}$, Limiting indices: $-14 \leq h \leq 17,-11 \leq k \leq 13$, $22 \leq 1 \leq 22$, Reflections collected / unique: $17883 / 5013$ [R(int) $=0.0246$ ], Completeness to theta $=99.8 \%$, Absorption correction: none, Refinement method: Full-matrix least-squares on $\mathrm{F}^{2}$, Data / restraints / parameters: 5013 / 0 / 316, Goodness-of-fit: 1.084, Final R indices [I>2sigma(I)]: R1a $=0.0375, w R 2 b=0.1057, R$ indices (all data) $: R 1 a=0.0494, w R 2 b=0.1091$, Largest diff. peak and hole : 0.465 and -0.485 e. $A^{-3}$.

\section{Compound 22}

A solution of ynamide 21 (200 mg, $0.651 \mathrm{mmol})$ and TCNE (83 mg, $0.651 \mathrm{mmol})$ in $\mathrm{CH}_{2} \mathrm{Cl}_{2}(10$ $\mathrm{mL}$ ) was stirred at r.t. for $18 \mathrm{~h}$. The mixture was concentrated under reduced pressure and purified by column chromatography (petroleum ether: $\mathrm{Et}_{2} \mathrm{O} 1: 0$ to 1:1) to give TCBD 22 (285 $\mathrm{mg}, 0.650 \mathrm{mmol}, 99 \%)$ as a brown solid. ${ }^{1} \mathrm{H}$ NMR $\left(400 \mathrm{MHz}, \mathrm{CDCl}_{3}\right) \delta 7.64(\mathrm{t}, J=7.4 \mathrm{~Hz}, 1 \mathrm{H})$, $7.49(\mathrm{t}, J=7.9 \mathrm{~Hz}, 2 \mathrm{H}), 7.43(\mathrm{dd}, J=8.5,1.2 \mathrm{~Hz}, 2 \mathrm{H}), 7.38-7.34(\mathrm{~m}, 3 \mathrm{H}), 7.10-7.13(\mathrm{~m}, 2 \mathrm{H})$, $4.87(\mathrm{~s}, 2 \mathrm{H}), 1.45$ (s, 9H). ${ }^{13} \mathrm{C}$ NMR $\left(100 \mathrm{MHz}, \mathrm{CDCl}_{3}\right) 164.3,161.4,150.4,134.5,134.4,130.3$, 129.8, 129.6, 129.3, 128.8, 127.2, 111.6, 111.3, 111.0, 111.0, 90.3, 87.5, 82.3, 53.4, 27.7. HRMS (ESI) calculated for $\mathrm{C}_{26} \mathrm{H}_{21} \mathrm{~N}_{5} \mathrm{NaO}_{2}[\mathrm{M}+\mathrm{Na}]^{+} 458.15929$, found 458.1591 .

\section{Compound 24}

A solution of ynamide 23 (105 mg, $0.277 \mathrm{mmol}$ ) and TCNE ( $35 \mathrm{mg}, 0.276 \mathrm{mmol}$ ) in $\mathrm{CH}_{2} \mathrm{Cl}_{2}$ (3 $\mathrm{mL}$ ) was stirred at r.t. for $18 \mathrm{~h}$. The mixture was concentrated under reduced pressure to give TCBD 24 (140 mg, $0.276 \mathrm{mmol}, 99 \%)$ as a bright yellow powder. ${ }^{1} \mathbf{H}$ NMR $(400 \mathrm{MHz}$, $\left.\mathrm{CDCl}_{3}\right) \delta 7.90(\mathrm{~d}, J=8.5 \mathrm{~Hz}, 2 \mathrm{H}), 7.49(\mathrm{~d}, J=8.1 \mathrm{~Hz}, 2 \mathrm{H}), 7.42(\mathrm{t}, J=7.5 \mathrm{~Hz}, 1 \mathrm{H}), 7.31(\mathrm{t}, J=7.7$ 
$\mathrm{Hz}, 2 \mathrm{H}), 7.10(\mathrm{~d}, J=7.1 \mathrm{~Hz}, 2 \mathrm{H}), 7.04(\mathrm{~d}, J=7.1 \mathrm{~Hz}, 4 \mathrm{H}), 4.79(\mathrm{~s}, 2 \mathrm{H}), 2.52(\mathrm{~s}, 3 \mathrm{H}) .{ }^{1} \mathbf{H}$ NMR $\left\{{ }^{19} \mathrm{~F}\right\}\left(400 \mathrm{MHz}, \mathrm{CDCl}_{3}\right) \delta 7.89(\mathrm{~d}, J=8.1 \mathrm{~Hz}, 2 \mathrm{H}), 7.48(\mathrm{~d}, J=8.1 \mathrm{~Hz}, 2 \mathrm{H}), 7.42(\mathrm{t}, J=7.6 \mathrm{~Hz}, 1 \mathrm{H})$, $7.30(\mathrm{t}, J=7.6 \mathrm{~Hz}, 2 \mathrm{H}), 7.09(\mathrm{~d}, J=7.6 \mathrm{~Hz}, 2 \mathrm{H}), 7.02(\mathrm{~s}, 4 \mathrm{H}), 4.79(\mathrm{~s}, 2 \mathrm{H}), 2.51(\mathrm{~s}, 3 \mathrm{H}) .{ }^{13} \mathrm{C}$ NMR $\left(100 \mathrm{MHz}, \mathrm{CDCl}_{3}\right) \delta 165.2\left(\mathrm{t}, J_{\mathrm{C}-\mathrm{F}}=128 \mathrm{~Hz}\right), 158.5,147.5,133.1,131.5(\mathrm{~d}, J=9.4 \mathrm{~Hz}), 131.1$, 131.0, 129.6, 129.5, 129.4, 128.2, 125.7 (d, $J=3.3 \mathrm{~Hz}$ ), 117.2, 117.0, 111.5, 111.4, 111.0, 110.9, $93.6(\mathrm{~d}, J=1.3 \mathrm{~Hz}), 81.7,52.6,21.9 .{ }^{19} \mathrm{~F} \mathrm{NMR}\left(376 \mathrm{MHz}, \mathrm{CDCl}_{3}\right) \delta-103.2$. HRMS (ESI) calculated for $\mathrm{C}_{28} \mathrm{H}_{18} \mathrm{FKN}_{5} \mathrm{O}_{2} \mathrm{~S} \quad[\mathrm{M}+\mathrm{K}]^{+}$546.08023, found 546.0801; calculated for $\mathrm{C}_{28} \mathrm{H}_{18} \mathrm{FN}_{5} \mathrm{NaO}_{2} \mathrm{~S}[\mathrm{M}+\mathrm{Na}]^{+} 530.10629$, found 530.1058. Crystal data: Crystallogenesis: liquid diffusion from a $\mathrm{CH}_{2} \mathrm{Cl}_{2}$ solution into cyclohexane; Formula: $\mathrm{C}_{31} \mathrm{H}_{24} \mathrm{FN}_{5} \mathrm{O}_{2} \mathrm{~S}$, Formula weight: 549.61, Temperature: $150 \mathrm{~K}$, Wavelength: $1.54184 \AA$, Crystal system: Triclinic, space group: $\mathrm{P}_{-1}$, Unit cell dimensions: $a=10.1604(3) \AA, b=11.6936(5) \AA, c=13.2402(5) \AA, \alpha=$ 115.472(4) ${ }^{\circ}, \beta=97.027(3)^{\circ}, \gamma=94.319(3)^{\circ}$, Volume: $1395.07(10) \AA^{3}, Z=2$, Calculated density: $1.308 \mathrm{Mg} / \mathrm{m}^{3}$, Absorption coefficient: $1.397 \mathrm{~mm}^{-1}, \mathrm{~F}(000): 572$, Crystal size: $0.296 \mathrm{x}$ $0.210 \times 0.207 \mathrm{~mm}^{3}$, Theta range for data collection: 3.754 to $70.729^{\circ}$, Limiting indices: $12<=\mathrm{h}<=9,-14<=\mathrm{k}<=14,-16<=\mathrm{k}<=15$, Reflections collected / unique: $13777 / 5330$ [R(int) = 0.0230], Completeness to theta $=67.684^{\circ}, 99.9 \%$, Absorption correction: Semi-empirical from equivalents, Max. and min. transmission: 1.00000 and 0.90963, Refinement method: Full-matrix least-squares on $F^{2}$, Data / restraints / parameters: 5330 / 0 / 363, Goodness-offit on $F^{2}: 1.054$, Final $R$ indices [I>2sigma(I)]: R1 $=0.0522, w R 2=0.1413, R$ indices (all data) : $\mathrm{R} 1=0.0555, \mathrm{WR} 2=0.1473$, Extinction coefficient: $0.0036(5)$, Largest diff. peak and hole: 1.888 and -0.387 e. $A^{-3}$.

\section{Compound 26}

A solution of ynamide 25 (291 mg, $0.894 \mathrm{mmol}$ ) and TCNE (116 mg, $0.906 \mathrm{mmol}$ ) in $\mathrm{CH}_{2} \mathrm{Cl}_{2}$ $(10 \mathrm{~mL})$ was stirred at r.t. for $18 \mathrm{~h}$. The mixture was first dark red and then turned orange with white precipitate. The mixture was concentrated under reduced pressure and purified by column chromatography ( $n$-pentane: $\mathrm{CH}_{2} \mathrm{Cl}_{2}$ 1:0 to 0:1) to give TCBD 26 (350 mg, 0.772 mmol, 86\%) as a dark yellow solid. ${ }^{1} \mathbf{H}$ NMR $\left(400 \mathrm{MHz}^{\mathrm{CDCl}}{ }_{3}\right) \delta 7.94(\mathrm{dt}, J=8.4,1.6 \mathrm{~Hz}, 2 \mathrm{H})$, $7.48(\mathrm{~d}, J=8.0 \mathrm{~Hz}, 2 \mathrm{H}), 7.43-7.38(\mathrm{~m}, 5 \mathrm{H}), 4.94(\mathrm{~s}, 2 \mathrm{H}), 2.51(\mathrm{~s}, 3 \mathrm{H}), 1.85(\mathrm{tt}, J=8.5,5.5 \mathrm{~Hz}$, $1 \mathrm{H}), 1.14-1.08(\mathrm{~m}, 2 \mathrm{H}), 0.99-0.94(\mathrm{~m}, 2 \mathrm{H}) .{ }^{13} \mathrm{C}$ NMR $\left(100 \mathrm{MHz}, \mathrm{CDCl}_{3}\right) \delta 172.1,159.5$, 147.6, 133.2, 131.9, 131.1, 130.0, 129.6, 129.5, 128.5, 111.3, 111.3, 111.1, 110.4, 93.3, 79.7, 52.9, 22.0, 18.2, 11.8. HRMS (ESI) calculated for $\mathrm{C}_{25} \mathrm{H}_{19} \mathrm{~N}_{5} \mathrm{NaO}_{2} \mathrm{~S}[\mathrm{M}+\mathrm{Na}]^{+} 476.1157$, found 476.1154. Crystal data: Crystallogenesis: liquid diffusion from a $\mathrm{CH}_{2} \mathrm{Cl}_{2}$ solution into cyclohexane; Formula: $\mathrm{C}_{25} \mathrm{H}_{19} \mathrm{~N}_{5} \mathrm{O}_{2} \mathrm{~S}$, Formula weight: 453.52, Temperature: $150 \mathrm{~K}$, Wavelength: $1.54184 \AA$, Crystal system: Triclinic, space group: $P_{-1}$, Unit cell dimensions: $a=$ 8.1626(4) $\AA, b=8.7035(5) \AA, c=16.8844(8) \AA, \alpha=91.953(4)^{\circ}, \beta=95.786(4)^{\circ}, \gamma=111.987(5)^{\circ}$, Volume: $1103.25(11) \AA^{3}, Z=2$, Calculated density: $1.365 \mathrm{Mg} / \mathrm{m}^{3}$, Absorption coefficient: $1.578 \mathrm{~mm}^{-1}, \mathrm{~F}(000): 472$, Crystal size: $0.5653 \times 0.0548 \times 0.0418 \mathrm{~mm}^{3}$, Theta range for data collection: 5.282 to $71.217^{\circ}$, Index ranges: $-10<=h<=6,-10<=k<=10,-20<=\mid<=20$, Reflections collected: 8920, Independent reflections: 4217 [R(int $)=0.0274]$, Completeness to theta $=$ $67.684^{\circ}, 99.9 \%$, Absorption correction: Gaussian, Max. and min. transmission: 0.943 and 0.684, Refinement method: Full-matrix least-squares on $\mathrm{F}^{2}$, Data / restraints / parameters: 4217 / 0 / 299, Goodness-of-fit on $F^{2}:$ 1.031, Final R indices [I>2sigma(I)]: R1 = 0.0387, wR2 = $0.1037, \mathrm{R}$ indices (all data) $: \mathrm{R} 1=0.0452, \mathrm{wR} 2=0.1086$, Extinction coefficient: $\mathrm{n} / \mathrm{a}$, Largest diff. peak and hole: 0.641 and -0.407 e. $A^{-3}$. 


\section{Compound 30}

A solution of ynamide 29 (43.0 mg, $0.161 \mathrm{mmol}$ ) and TCNE $(23.0 \mathrm{mg}, 0.178 \mathrm{mmol})$ in $\mathrm{CH}_{2} \mathrm{Cl}_{2}$ $(10 \mathrm{~mL})$ was stirred at r.t. for $18 \mathrm{~h}$. The mixture was concentrated under reduced pressure and purified by column chromatography (pentane: $\mathrm{CH}_{2} \mathrm{Cl}_{2} 1: 1$ to $\mathrm{CH}_{2} \mathrm{Cl}_{2}$ ) to give TCBD 30 (53.0 mg, $0.134 \mathrm{mmol}, 83 \%)$ as a purple solid. ${ }^{1} \mathrm{H} \mathbf{~ N M R}\left(400 \mathrm{MHz}, \mathrm{CDCl}_{3}\right) \delta 8.03$ (ddd, $J=7.6$, 1.4, $0.7 \mathrm{~Hz}, 2 \mathrm{H}), 7.75-7.71(\mathrm{~m}, 2 \mathrm{H}), 7.69-7.64(\mathrm{~m}, 1 \mathrm{H}), 7.54$ (ddd, $J=8.3,7.3,1.3 \mathrm{~Hz}, 4 \mathrm{H})$, $7.48(\mathrm{td}, J=7.5,1.0 \mathrm{~Hz}, 2 \mathrm{H}), 7.44(\mathrm{dt}, J=8.2,0.8 \mathrm{~Hz}, 2 \mathrm{H}) .{ }^{13} \mathrm{C} \mathrm{NMR}\left(100 \mathrm{MHz}, \mathrm{CDCl}_{3}\right) \delta 162.8$, 156.3, 138.2, 135.1, 131.3, 130.4, 130.2, 127.6, 126.7, 125.6, 121.6, 112.7, 112.0, 111.2, 110.8, 110.7, 91.6, 83.3. HRMS (ESI) calculated for $\mathrm{C}_{26} \mathrm{H}_{14} \mathrm{~N}_{5}[\mathrm{M}+\mathrm{H}]^{+} 396.12492$, found 396.1249. UV-visible spectroscopy $\left(\mathrm{CH}_{2} \mathrm{Cl}_{2}\right): \lambda_{\max }(\log \varepsilon)=279$ (4.08), 315 (3.84), 511 (3.20) nm. Crystal data: Crystallogenesis: liquid diffusion from a $\mathrm{CH}_{2} \mathrm{Cl}_{2}$ solution into cyclohexane, Formula: $\mathrm{C}_{26} \mathrm{H}_{13} \mathrm{~N}_{5}$, Temperature: $250 \mathrm{~K}$, Wavelength: $1.54184 \AA$, Crystal system: Orthorhombic, space group, $\mathrm{P} 2{ }_{1}{ }_{2}{ }_{2}{ }_{1}$, Unit cell dimensions: $a=7.9516(3) \AA, b=12.0897(4) \AA$, $c=21.5176(7) \AA, \alpha=90^{\circ}, \beta=90^{\circ}, \gamma=90^{\circ}$, Volume: 2068.54(12) $\AA^{3}, Z=4$, Calculated density: $1.270 \mathrm{Mg} / \mathrm{m}^{3}$, Absorption coefficient $0.621 \mathrm{~mm}^{-1}, \mathrm{~F}(000)$ : 816 , Crystal size: $0.2708 \times 0.0668 \mathrm{x}$ $0.0367 \mathrm{~mm}^{3}$, Theta range for data collection: 4.194 to $72.112^{\circ}$, Limiting indices: $-9<=\mathrm{h}<=6$, $14<=k<=13,-26<=\mid<=25$, Reflections collected / unique: $8409 / 4043$ [R(int) = 0.0220], Completeness to theta $=67.684^{\circ}, 99.9 \%$, Absorption correction: Gaussian, Max. and min. transmission: 0.979 and 0.910, Refinement method: Full-matrix least-squares on F2, Data / restraints / parameters: 4043 / 0 / 280, Goodness-of-fit on F2: 1.052, Final R indices [l>2sigma(I)]: R1 =0.0339, wR2 =0.0870, $\mathrm{R}$ indices (all data) $: \mathrm{R} 1=0.0377, \mathrm{wR2}=0.0870$, Absolute structure parameter: $-0.1(2)$, Extinction coefficient: $n / a$, Largest diff. peak and hole: 0.089 and -0.176 e. $A^{-3}$.

\section{Compound 32}

A solution of ynamide 31 (91.0 mg, $0.419 \mathrm{mmol}$ ) and TCNE $(53.7 \mathrm{mg}, 0.419 \mathrm{mmol})$ in $\mathrm{CH}_{2} \mathrm{Cl}_{2}$ $(10 \mathrm{~mL})$ was stirred at $\mathrm{r}$.t. for $18 \mathrm{~h}$. The mixture was concentrated under reduced pressure and purified by column chromatography (pentane: $\mathrm{CH}_{2} \mathrm{Cl}_{2} 1: 1$ to $\mathrm{CH}_{2} \mathrm{Cl}_{2}$ ) to give TCBD 32 $(85.0 \mathrm{mg}, 0.246 \mathrm{mmol}, 59 \%)$ as a very slimy dark red liquid. ${ }^{1} \mathbf{H} \mathbf{N M R}\left(400 \mathrm{MHz}, \mathrm{CDCl}_{3}\right) \delta 7.82$ $(\mathrm{dt}, J=8.6,1.8 \mathrm{~Hz}, 2 \mathrm{H}), 7.74(\mathrm{ddd}, J=7.6,2.0,1.2 \mathrm{~Hz}, 1 \mathrm{H}), 7.68-7.60(\mathrm{~m}, 4 \mathrm{H}), 7.40-7.32(\mathrm{~m}$, $2 \mathrm{H}), 7.32-7.28(\mathrm{~m}, 1 \mathrm{H}), 7.00(\mathrm{dd}, J=3.7,0.8 \mathrm{~Hz}, 1 \mathrm{H}) .{ }^{13} \mathrm{C}$ NMR $\left(100 \mathrm{MHz}, \mathrm{CDCl}_{3}\right): \delta 162.2$, $157.3,135.4,134.9,131.2,130.9,130.4,130.3,127.6,125.8,125.7,123.3,114.0,112.8$, 111.7, 111.6, 111.0, 110.3, 90.4, 76.6. HRMS (ESI) calculated for $\mathrm{C}_{22} \mathrm{H}_{12} \mathrm{~N}_{5}[\mathrm{M}+\mathrm{H}]^{+} 346.10927$, found 346.1096. UV-visible spectroscopy $\left(\mathrm{CH}_{2} \mathrm{Cl}_{2}\right): \lambda_{\max }(\log \varepsilon)=258(4.25), 336(4.18), 443$ (3.57) $\mathrm{nm}$.

\section{Compound 34}

A solution of ynamide $33(50 \mathrm{mg}, 0.10 \mathrm{mmol})$ and TCNE (26 mg, $0.20 \mathrm{mmol})$ in $\mathrm{CH}_{2} \mathrm{Cl}_{2}(2 \mathrm{~mL})$ was stirred at r.t. for $16 \mathrm{~h}$. The mixture was concentrated under reduced pressure and purified by column chromatography $\left(\mathrm{CH}_{2} \mathrm{Cl}_{2}\right.$ : cyclohexane 9:1) to give TCBD 34 (49 mg, 0.080 mmol, $79 \%)$ as an orange-red solid. ${ }^{1} \mathbf{H}$ NMR $\left(400 \mathrm{MHz}, \mathrm{CDCl}_{3}\right) \delta 7.84(\mathrm{~d}, J=8.3 \mathrm{~Hz}, 2 \mathrm{H}), 7.74$ $(\mathrm{d}, J=8.4 \mathrm{~Hz}, 2 \mathrm{H}), 7.65(\mathrm{~d}, J=8.8 \mathrm{~Hz}, 2 \mathrm{H}), 7.51(\mathrm{~d}, J=8.8 \mathrm{~Hz}, 2 \mathrm{H}), 7.46(\mathrm{~d}, J=8.0 \mathrm{~Hz}, 2 \mathrm{H}), 7.41$ $(\mathrm{d}, J=8.0 \mathrm{~Hz}, 2 \mathrm{H}), 3.45(\mathrm{~s}, 3 \mathrm{H}), 3.21(\mathrm{~s}, 3 \mathrm{H}), 2.51(\mathrm{~s}, 3 \mathrm{H}), 2.48(\mathrm{~s}, 3 \mathrm{H}) .{ }^{13} \mathrm{C}$ NMR $(100 \mathrm{MHz}$, $\mathrm{CDCl}_{3}$ ) $\delta 164.3,163.6,147.7,145.5,133.4,132.3,131.5,131.1,130.3,130.2,129.6,128.3$, $127.9,111.9,111.9,110.8,110.5,90.7,88.8,80.2,69.8,41.2,39.3,27.1,22.0,21.9$. HRMS 
(ESI) calculated for $\mathrm{C}_{32} \mathrm{H}_{24} \mathrm{~N}_{6} \mathrm{NaO}_{4} \mathrm{~S}_{2}[\mathrm{M}+\mathrm{Na}]^{+}$643.1198, found 643.1198. UV-visible spectroscopy $\left(\mathrm{CH}_{2} \mathrm{Cl}_{2}\right): \lambda_{\max }(\log \varepsilon)=276(4.48), 313(4.41), 416(4.17) \mathrm{nm}$.

\section{Compound 36}

A solution of ynamide $35(52 \mathrm{mg}, 0.080 \mathrm{mmol})$ and TCNE $(20 \mathrm{mg}, 0.16 \mathrm{mmol})$ in $\mathrm{CH}_{2} \mathrm{Cl}_{2}(0.8$ $\mathrm{mL}$ ) was stirred at r.t. for $16 \mathrm{~h}$. The reaction mixture was purified by column chromatography (pentane:EtOAc 8:2 to 7:3) to give TCBD $36(61 \mathrm{mg}, 0.078 \mathrm{mmol}, 98 \%)$ as a red solid. ${ }^{1} \mathbf{H}$ NMR $\left(400 \mathrm{MHz}, \mathrm{CDCl}_{3}\right) \delta 7.75(\mathrm{~d}, J=8.3 \mathrm{~Hz}, 2 \mathrm{H}), 7.62(\mathrm{~d}, J=8.2 \mathrm{~Hz}, 2 \mathrm{H}), 7.31-7.03(\mathrm{~m}, 14 \mathrm{H})$, $6.73-6.64(\mathrm{~m}, 2 \mathrm{H}), 4.74(\mathrm{~s}, 2 \mathrm{H}), 4.46(\mathrm{~s}, 2 \mathrm{H}), 2.31(\mathrm{~s}, 6 \mathrm{H}) .{ }^{13} \mathrm{C} \mathrm{NMR}\left(100 \mathrm{MHz}, \mathrm{CDCl}_{3}\right) \delta 158.9$, $154.4,148.1,146.1,137.6,136.2,134.6,134.0,133.3,132.4,132.3,131.9,131.3,130.6$, $130.1,130.0,129.8,129.3,129.3,129.2,128.1,126.4,126.2,112.8,112.2,111.7,111.6$, 95.4, 84.4, 65.5, 55.7, 53.2, 21.6, 21.5. HRMS (ESI) calculated for $\mathrm{C}_{42} \mathrm{H}_{30} \mathrm{~N}_{6} \mathrm{NaO}_{4} \mathrm{~S}_{3}[\mathrm{M}+\mathrm{Na}]^{+}$ 801.1388, found 801.1376. UV-visible spectroscopy $\left(\mathrm{CH}_{2} \mathrm{Cl}_{2}\right): \lambda_{\max }(\log \varepsilon)=285(4.26), 337$ (4.08), $468(4.25) \mathrm{nm}$.

\section{Compound 38}

A solution of ynamide 37 ( $37 \mathrm{mg}, 0.045 \mathrm{mmol})$ and TCNE (12 mg, $0.091 \mathrm{mmol})$ in $\mathrm{CH}_{2} \mathrm{Cl}_{2}(0.5$ $\mathrm{mL}$ ) was stirred at r.t. for $16 \mathrm{~h}$. The reaction mixture was purified by column chromatography $\left(\mathrm{CH}_{2} \mathrm{Cl}_{2}\right.$ to $\mathrm{CH}_{2} \mathrm{Cl}_{2}: \mathrm{Et}_{2} \mathrm{O}$ 9:1) to give TCBD $38(45 \mathrm{mg}, 42 \mathrm{mmol}, 92 \%)$ as a purple solid. ${ }^{1} \mathrm{H}$ NMR $\left(400 \mathrm{MHz}, \mathrm{CDCl}_{3}\right) \delta 7.96(\mathrm{~d}, J=8.3 \mathrm{~Hz}, 4 \mathrm{H}), 7.55(\mathrm{t}, J=7.6 \mathrm{~Hz}, 2 \mathrm{H}), 7.49(\mathrm{~d}, J=8.3 \mathrm{~Hz}$, $4 \mathrm{H}), 7.43(\mathrm{t}, J=7.6 \mathrm{~Hz}, 1 \mathrm{H}), 7.38-7.18(\mathrm{~m}, 12 \mathrm{H}), 7.08-6.97(\mathrm{~m}, 8 \mathrm{H}), 4.82(\mathrm{~s}, 4 \mathrm{H}), 2.52(\mathrm{~s}$, 6H). ${ }^{13} \mathrm{C} \mathrm{NMR}\left(100 \mathrm{MHz}, \mathrm{CDCl}_{3}\right) \delta 164.0,159.2,150.8,147.6,144.5,133.2,131.4,131.2$, $131.1,130.8,130.0,129.7,129.4,128.6,127.8,127.7,123.9,122.8,112.2,112.1,111.6$, 111.4, 90.0, 81.2, 52.7, 22.0. HRMS (ESI) calculated for $\mathrm{C}_{62} \mathrm{H}_{42} \mathrm{~N}_{11} \mathrm{NaO}_{4} \mathrm{~S}_{2}[\mathrm{M}+\mathrm{H}+\mathrm{Na}]^{+}$ 1090.26821, found 1090.26766. UV-visible spectroscopy $\left(\mathrm{CH}_{2} \mathrm{Cl}_{2}\right): \lambda_{\max }(\log \varepsilon)=306(5.05)$, 335 (4.98), 579 (4.49) nm.

\section{Acknowledgments}

M. Betou and A. Sallustrau thank the Région Bretagne for a post-doctoral grant. J.-C. Guillemin is acknowledged for proofreading the manuscript.

[1] a) M. Kivala, F. Diederich, Acc. Chem. Res. 2009, 42, 235-248; b) S.-i. Kato, F. Diederich, Chem. Commun. 2010, 46, 1994-2006.

[2] a) X. Wu, J. Wu, Y. Liu, A. K. Y. Jen, J. Am. Chem. Soc. 1998, 121, 472-473; b) C. Cai, I. Liakatas, M.-S. Wong, M. Bösch, C. Bosshard, P. Günter, S. Concilio, N. Tirelli, U. W. Suter, Org. Lett. 1999, 1, 1847-1849; c) M. T. Beels, M. S. Fleischman, I. Biaggio, B. Breiten, M. Jordan, F. Diederich, Opt. Mater. Express 2012, 2, 294-303; d) Y. Mi, P. Liang, Z. Yang, D. Wang, H. Cao, W. He, H. Yang, Lian Yu, ChemistryOpen 2016, 5, 71-77.

[3] a) T. Mochida, S. Yamazaki, J. Chem. Soc. Dalton Trans. 2002, 3559-3564; b) Y. Morioka, N. Yoshizawa, J.-i. Nishida, Y. Yamashita, Chem. Lett. 2004, 33, 1190-1191; c) S.-i. Kato, M. Kivala, W. B. Schweizer, C. Boudon, J.-P. Gisselbrecht, F. Diederich, Chem. Eur. J. 2009, 15, 8687-8691; d) R. Garcia, M. A. Herranz, M. R. Torres, P.-A. Bouit, J. L. Delgado, J. Calbo, P. M. Viruela, E. Orti, N. Martin, J. Org. Chem. 2012, 77, 10707-10717; e) F. G. Perrin, G. Kiefer, L. Jeanbourquin, S. Racine, D. Perrotta, J. Waser, R. Scopelliti, K. Severin, Angew. Chem. Int. Ed. 
2015, 54, 13393-13396; f) S.-i. Kato, H. Noguchi, S. Jin, Y. Nakamura, Asian J. Org. Chem. 2016, 5, 246 - 256; g) T. Shoji, S. Ito, T. Okujima, N. Morita, Eur. J. Org. Chem. 2011, 51345140; h) S. Niu, G. Ulrich, P. Retailleau, R. Ziessel, Tetrahedron Lett. 2011, 52, 4848-4853; i) A. Leliège, P. Blanchard, T. Rousseau, J. Roncali, Org. Lett. 2011, 13, 3098-3101; j) Z. Jin, D. Wanga, X. Wanga, P. Liang, Y. Mi, H. Yang Tetrahedron Lett. 2013, 54, 4859-4864.

[4] a) T. Michinobu, J. C. May, J. H. Lim, C. Boudon, J.-P. Gisselbrecht, P. Seiler, M. Gross, I. Biaggio, F. Diederich, Chem. Commun. 2005, 737-739; b) T. Shoji, S. Ito, K. Toyota, M. Yasunami, N. Morita, Chem. Eur. J. 2008, 14, 8398-8408; c) T. Shoji, J. Higashi, S. Ito, T. Okujima, M. Yasunami, N. Morita, Chem. Eur. J. 2011, 17, 5116-5129; (d) D. Koszelewski, A. Nowak-Król, D. T. Gryko, Chem. Asian J. 2012, 7, 1887-1894.

[5] H.C. Kolb, M. G. Finn, K. B. Sharpless, Angew. Chem. Int. Ed. 2001, 40, 2004-2021.

[6] a) G. Evano, A. Coste, K. Jouvin, Angew. Chem. Int. Ed. 2010, 49, 2840-2859; b) K. A. DeKorver, H. Li, A. G. Lohse, R. Hayashi, Z. Lu, Y. Zhang, R. P. Hsung, Chem. Rev. 2010, 110, $5064-5106$.

[7] M. Betou, N. Kerisit, E. Meledje, Y. R. Leroux, C. Katan, J.-F. Halet, J.-C. Guillemin, Y. Trolez, Chem. Eur. J. 2014, 20, 9553-9557.

[8] C. M. Reisinger, P. Rivera-Fuentes, S. Lampart, W. B. Schweizer, F. Diederich, Chem. Eur. J. 2011, 17, 12906-12911.

[9] Y. Zhang, R. P. Hsung, M. R. Tracey, K. C. M. Kurtz, E. L. Vera, Org. Lett. 2004, 6, 11511154.

[10] K. Jouvin, A. Coste, A. Bayle, F. Legrand, G. Karthikeyan, K. Tadiparthi, G. Evano, Organometallics 2012, 31, 7933-7947.

[11] J. R. Dunetz, R. L. Danheiser, Org. Lett. 2003, 5, 4011-4014.

[12] T. Hamada, X. Ye, S. S. Stahl, J. Am. Chem. Soc. 2008, 130, 833-835.

[13] T. Shoji, S. Ito, T. Okujima, N. Morita, Org. Biomol. Chem. 2012, 10, 8308-8313.

[14] a) G. Jayamurugan, J.-P. Gisselbrecht, C. Boudon, F. Schoenebeck, W. B. Schweizer, B. Bernet, F. Diederich, Chem. Commun. 2011, 47, 4520-4522; b) G. Jayamurugan, A. D. Finke, J.-P. Gisselbrecht, C. Boudon, W. B. Schweizer, F. Diederich, J. Org. Chem. 2014, 79, 426-431; C) N. Kerisit, A. D. Finke, N. Trapp, Y. R. Leroux, J.-C. Guillemin, Y. Trolez, F. Diederich, Tetrahedron 2015, 71, 4393-4399.

[15] Y. Tokimizu, M. Wieteck, M. Rudolph, S. Oishi, N. Fujii, A. S. K. Hashmi, H. Ohno, Org. Lett. 2015, 17, 604-607.

[16] L. V. Graux, H. Clavier, G. Buono, ChemCatChem 2014, 6, 2544- 2548.

[17] A. R. Katritzky, W. H. Ramer, J. Org. Chem. 1985, 50, 852-856.

[18] A. Sagadevan, A. Ragupathi, C.-C. Li, J. R. Hwu, K. C. Hwang, Green Chem. 2015, 17, 1113-1119.

[19] A. H. Sato, K. Ohashi, K. Ito, T. Iwasawa, Tetrahedron Lett. 2013, 54, 2878-2881.

[20] T. Okuno, H. Iwahashi, Acta Cryst. 2013, E69, 0665.

[21] a) M. Kivala, C. Boudon, J.-P. Gisselbrecht, P. Seiler, M. Gross, F. Diederich, Chem. Commun. 2007, 4731-4733; b) T. Shoji, S. Ito, K. Toyota, T. Iwamoto, M. Yasunami, Noboru Morita, Eur. J. Org. Chem. 2009, 4316-4324; c) X. Tang, W. Liu, J. Wu, C.-S. Lee, J. You, P. Wang, J. Org. Chem. 2010, 75, 7273-7278; d) T. Shoji, J. Higashi, S. Ito, T. Okujima, M. Yasunamie, N. Morita, Org. Biomol. Chem. 2012, 10, 2431-2438.

[22] M. Betou, A. Sallustrau, Y. Trolez, Tetrahedron Lett. 2015, 56, 4627-4630. 
[23] a) T. Michinobu, C. Boudon, J.-P. Gisselbrecht, P. Seiler, B. Frank, N. N. P. Moonen, M. Gross, F. Diederich, Chem. Eur. J. 2006, 12, 1889-1905; b) N. Krauße, M. Kielmann, J. Ma, H. Butenschön, Eur. J. Org. Chem. 2015, 2622-2631.

[24] a) T Shoji, E. Shimomura, M. Maruyama, A. Maruyama, S. Ito, T. Okujima, K. Toyota, N. Morita, Eur. J. Org. Chem. 2013, 7785-7799; b) T. Shoji, N. Kamata, A. Maruyama, S. Ito, T. Okujima, Bull. Chem. Soc. Jpn. 2015, 88, 1338-1346.

[25] C. Dengiz, B. Breiten, J.-P. Gisselbrecht, C. Boudon, N. Trapp, W. B. Schweizer, F. Diederich, J. Org. Chem. 2015, 80, 882-896.

[26] J. Ohshita, T. Kajihara, D. Tanaka, Y. Ooyama, J. Organomet. Chem. 2014, 749, 255-260.

[27] M. Sekita, B. Ballesteros, F. Diederich, D. M. Guldi, G. Bottari, T. Torres, Angew. Chem. Int. Ed. 2016, 55, 5560-5564.

[28] Z. Pokladek, N. Ripoche, M. Betou, Y. Trolez, O. Mongin, J. Olesiak-Banska, K. Matczyszyn, M. Samoc, M. G. Humphrey, M. Blanchard-Desce, F. Paul, Chem. Eur. J. 2016, 22, 10155-10167.

[29] a) A. Altomare, M. Burla, M. Camalli, G. L. Cascarano, C. Giacovazzo, A. Guagliardi, A. G. G. Moliterni, G. Polidori, G. Spagna, G. J. Appl. Crystallogr. 1999, 32, 115-119; b) G. M. Sheldrick, Acta Cryst. 2015, A71, 3-8.

[30] G. M. Sheldrick (1997) SHELXL97. Program for the refinement of crystal structures. University of Göttingen, Germany. 